\title{
RESEARCH \\ A PERSONNEL PROFILE OF PROFESSIONAL NURSES IN THE J.D. ALLEN OPERATING THEATRE COMPLEX OF BARAGWANATH HOSPITAL
}

\author{
E.F. Smith and H.H.M. Uys
}

\section{bstract}

In this exploratory descriptive study an attempt was made to develop a profile of professional nurses in the J.D. Allen operating theatre complex of Baragwanath haspital. Aspects of significance have been extracted from the analysed data and highlighted as trends, not only of demographic nature but also in nursing education and practice, with specific reference to operating theatre nursing. Problem areas have been indicated and recommendations suggested.

This profile could be used as a staff development tool. It also would be possible to plan more rational staff structure considering future advances.

\section{Opsomming}

In hierdie verkennende, beskrywende studie word gepoog om 'n profiel van professionele verpleegkundiges in die J.D. Allen operasiesaalkompleks van Baragwanalh hospitcal te ontwikkel. Aspekte van belang is van die geanuliseerde data ontneem en as tendense uitgelig nie net van demografiese aard nie maar ook in verpleegkundige onderwys en praktyk met spesifieke verwysing na operasiesaalverpleegkunde. Probleemareas is aangedui en aanbevelings voorgestel.

ierdie profiel kan verseker as personeelontwikkelingsinstrument gebruik word. Die beplanning van ' $n$ meer rasionele personeelstruktuur wat toekomstige vooruitgang in ag neem, is ook moonilik.

\section{TIIE PROBLEM}

Introduction

Since the rescarcher's appointment as the nursing manager to the J.D. Allen operating theatre complex of Baragwanath Ilospital in 1983, an attempt was made to develop and establish an organizational staff structure. The abilities of a number of senior professional nurses, identified through observation and discussion, had been utilized in the structure since there was no detailed recorded information on the present personnel.

The main and most valuable component of an organizational structure is the human resource element which is always subjected to change and professional mobility and may cncompass

- promotion within the existing structure
- transfer to another ficld of nursing in vicw of changed attitudes or the acquisition of higher nursing qualifications

- resignation or termination

- expansion of existing servicc

* retirement

- death

(13calty and Schncier, 1982:30)

$\Lambda$ nursing manager never can be totally accurate in predicling what effect changes in human resources may have on her organizational situation. Nevertheless, she can anticipate and plan the extent of these changes which will cnable her to diminish possible adverse effects. She may even lum new circumstances into opportunities.

\section{Statement of the Problem}

Since 1983 to date there has been no recorded profile of professional nurses in the J.D. Nlen operating theatre complex of Baragwanath hospital. This poses problems in personnel management such as ethnic compatability and preparation for retirement or promotion, only to name a few.

\section{AIM OF TIIE STUDY}

The purpose of this study is to construct a complete and written profile of all professional nurses in the J.D. Allen operating theatre complex of Baragwanath Hospilal.

Objectives of the study

* to determinc and analyse, for cach professional nurse, the following details:-

- particular biographical data

- cducational standard

- nursing qualifications

- non-nursing qualifications

- experience in operating thealres nursing

- To identify some trends in operating thealre nursing

* To discuss the total professional nurse profile

* To computerise individual profiles for all professional nurses as an aid to personnel management activities

Keview of the Literature

Litcrature was studied as background to the survey and the following aspects of interest were revealed.

\section{Definition of a Personnel Profile}

Brink (1988:1) refers to the term as "an outline or schematic description of the main features or characteristics of a set of individuals".

Beach (1980:188) speaks of an "inventory of personnel" or "manpower information system" consisting of up-to-datc information on certain catcgories of personnel. A similar view comes from Beatty and Schneicr (1982:31). 


\section{Uses of a Personnel Profile}

A personnel profile provides baseline information about the manpower status in a department or an organization which would be available for future requirements. If identifications and analysis of the goals of an organisation is the first phase of planning, a personnel profile will facilitate future manpower planning and may be considered as the second phase of this planning process. (Beach, 1980:188; Beatty and Schneier 1982:31; Pera 1988:13).

More specifically, Beach (1980:31-32) identifies several important uses for such a profile, which are to:-

* ascertain the need for upgrading skills, abilities and knowledge among present personnel

- identify abilities of personnel within the department/organization for specific post vacancies

- monitor progress toward meeting the demands of the time and knowledge explosion (Brink 1988:1)

- facilitate opportunities for personnel to satisfy professional aspirations through development and promotion.

\section{Data for a Personnel Profile}

Practices vary as to how much information should be contained in a profile. Biographical, educational and professional background data have been included in nursing profile studies by Brink (1988:2), Pera (1988:14-15) and Paton (1988:5) on an individually selective basis which suggests that data selection format be flexible.

Gillies (1982:191-192) excludes biographical data and concentrates on personnel education and numbers in accordance with job classifications. She also includes length of service, employment and residential variables in constructing a nursing personnel profile.

\section{Educational Standard Patterns}

One is aware that the average educational levels for Black women have increased considerably over the past few decades. Departmental personnel, whether professional or non-professional, forward a constant flow of requests for accommodation of their formal learning needs and provision of learning opportunities which have to be considered in a master staff development programme.

Paton (1988:5) indicates in her study on the profile of nurse educators that school qualifications of the younger respondents appear to be higher (matriculation) than those of the older group. The significant aspect of this observation is that $45 \%$ of the respondents were Black.

Becker (1972:180) pointed out the significance of this educational trend nearly two decades ago and noted that a dominant feature of Black urbanization is the educational opportunities offered for the social advancement of women.
Demographic Patterns as part of Biographical Data

The acquisition of higher education and lately, home ownership by Black women have changed traditional roles of male sexual dominance (Becker, 1972:180; Researcher's experience)

Through this trend it could be assumed that the age of motherhood and fertility rates in particular, also may be influenced. Raubenheimer (1987:107) offers support for this view by indicating that the urbanized Black population rate under the age of 15 years at $17 \%$ is considerably lower than the $46 \%$ rate of rural areas. Rhoodie \& Swart (1971:109), with reference to the 1960 population census, indicate an average number of children for women with a diploma qualification of 2.02 and for those with a degree of 2.1 .

From these few points raised, one gathers that these issues are some of the implications of acculturation (abandonment) and deculturation (adaptation) which are consequential when members of different cultural groups have contact over an extended period of time (Myburgh, 1981:8-9; Terry, 1963).

\section{Nursing Education Patterns}

Professional nurses with a Bachelor's degree in nursing education or nursing administration are emerging slowly in direct patient care positions as a result of saturated fields in nursing education and administration (Paton 1988:5). This trend, especially among Black professional nurses, seems to reflect the American pattern of more than a decade ago. The American Nurses Association projected that the minimum preparation for professional nurses of a Bachelor's degree in nursing would be an established prerequisite in 1985 (DeBella 1986:128). In both instances, the underlying determinant is the expectation of liberation through education.

\section{Non-nursing Qualifications among} Professional Nurses

In spite of intensive scanning of literature, little has been found in this regard. Paton (1988:5) mentions that respondents have obtained various non-nursing qualifications but she gives no reference; one is aware, however, that many professional nurses possess non-nursing qualifications and often a casual reference is made to the existence of these during conversations on a personal basis.

\section{Nursing Practice Patterns}

The age of technology and the explosion of knowledge is on hand. The role of high technology is evident already in the treatment setting of health care institutions (Sanford in Hein and Nicholson, 1986:385). In the curative setting, the area concerned in this study, highly sophisticated endoscopic and non-invasive equipment gradually is replacing some elementary surgical instrumentation and consequent change in procedures requires new knowledge, skills and cost-control measures.

Nursing specialities and services have proliferated which has resulted in the need for more organization and an increased demand for middle managers. Oprating theatre units, too, need more managers who are clinical specialists in their respective fields. Because of ever-increasing reliance on machinery and equipment - such as in the anaesthetic, ophthalmological, oto-rhino-laryngological, orthopaedic, neurosurgical and cardio-thoracic disciplines to name a few - problems of storage, service and distribution have been created and subsequently call for specialised materials management (Sanford in Hein and Nicholson, 1986:386)

A natural progression in the development of nursing specialization is the evolvement of super-specialization (Felder in Hein and Nicholson, 1986:66) which is particularly evident in operating theatre nursing. Within a surgical speciality such as orthopaedic surgery, nursing specialists in spinal surgery, major joint reconstruction or micro neuro-vascular limb surgery are emerging.

But the clinical nursing specialists in the South African context are not on par with their American counterparts who must hold a master's degree with their clinical expertic concentrated in specific areas of clinical nurs (Hamric and Spross 1983:40). Not only do they have expectations of higher formal education for the clinical nurse specialists, but the emergence of super-specialization requires greater coordination and participative management to avoid fragmentation of scrvice within a department as suggested by Sanford (Hein and Nicholson, 1986:390).

Participative management not only allows the clinical nurse specialists to enact their multifaceted roles of implementing theory-based practice, teaching, consultation and research (Hamric and Spross 1983:41) but calls for a scientific approach to nursing management. To deal effectively with the complexity of health care delivery, a consputer information system is the ultimate aid to management activites such as determining the human resource status and planning future requirements. (Gillies 1982:381)

Experience of all categories of professic nurses

The only South African literature found to make any reference to experience of personnel in the operating theatre is that of Hamilton's study $(1988: 151)$. Forty $(81,6 \%)$ of her respondents were professional nurses in charge of operating theatres with more than five years experience in their field. These are considered to be experts, with which conclusion the researcher does not agree as the term was not qualified.

Groah (1983:39-92) dedicates two chapters in her book to job descriptions for the different categories of nursing personnel in the operating and recovery rooms within the American context. The emphasis is on academic qualifications rather than on clinical experience in this discipline. Two to three years clinical experience with an additional one to two years management expcrience are the minimum requirements for the post of Nursing Director or Operating Room Supervisor.

Should the candidate possess a Master's degree, less clinical experience is required. The opposite holds true for a nurse with a Baccalaureate degree. 


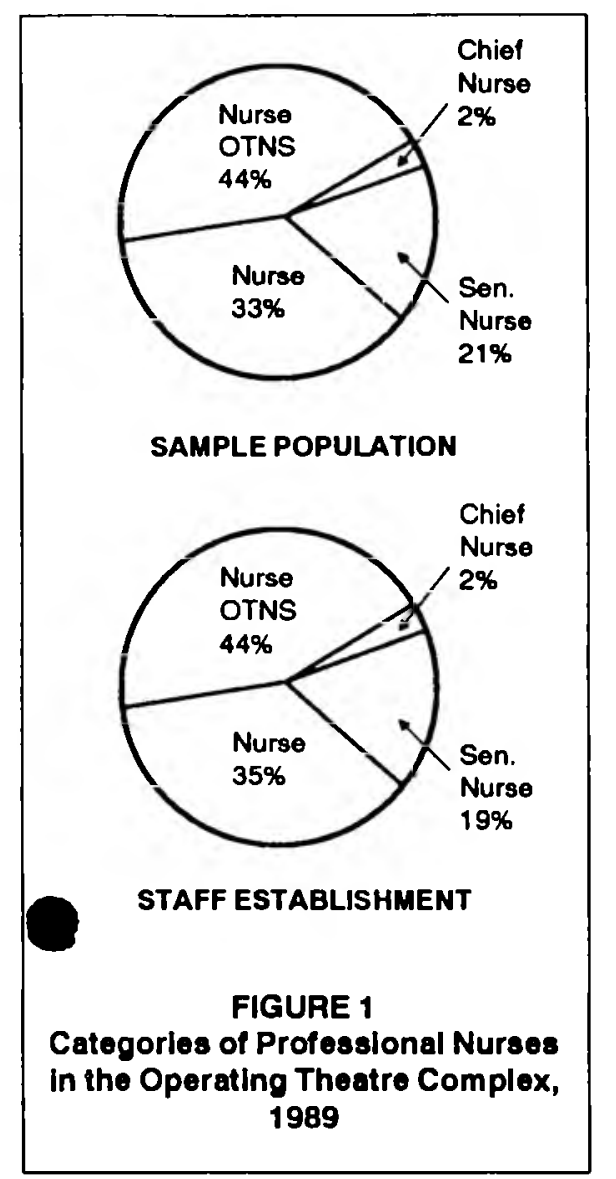

For the post of a Clinical Nurse IV and V - a senior professional nurse and clinical nurse specialist respectively - the minimum requirement is two/threc years of clinical experience with at least experience of onc year in a specific area of specialization. For the Clinical Nurse IV a Baccalaurcatc or Master's degree is required and for the Clinical Nurse $V$ a Master's or Doctoral degree. As the level of the Clinical Nurse drops, so does the required minimum of experience.

\section{RESEARCII METIIOD}

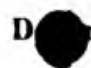

This is a exploratory descriptive study of the profile of professional nurses in the J.I. Allen operating theatre complex of Baragwanath hospital as reflected in July 1989.

\section{Population}

All professional nurses assigned to the J D Allen operating theatres complex in accordance with the official allocation list, including those professional nurses who are on accouchment leave or semi-permanent transfer to the cardio-thoracic operating theatres of the Johannesburg hospital; thus a $100 \%$ sample was achicved.

\section{The Instrument}

A structured questionnaire was developed which enables the researcher systematically to analyse all relevant data. Where returned questionnaires had very relevant data omitted, a telephonic request to the persons concerned was made through the rescarcher's depuly in the opcrating theatre complex. This information was acquired in written form and was entered on appropriate form by the rescarcher. The questionnaires were anonymous but coded by the researcher to facilitate control. $\wedge$ self-addressed envelope to the researcher was supplicd with cach questionnaire. Questionnaires were relurned in sealed scif-addressed envelopes and placed in a post box specially supplied in the department.

\section{Analysis of Datu}

Frequency and percentage distributions were the main melhods used for analysing the data.

\section{FINDINGS AND RESULTS}

\section{The Sample}

Out of a total staff establishment of $\mathbf{1 3 9}$ professional nurses, 131 questionnaires were returned but two had been spoilt. The sample used therefore was 129 (92\%) which is secn as a realistic represcntalion of the total staff establishment. Their queslionnaires have been analysed and the findings follow.

\section{Categories}

In the sample, $3(2,3 \%)$ are Chicf Professional Nurses, $27(20,9 \%)$ are Senior Professional Nurses, $57(44,2 \%)$ are Professional Nurses with Opcrating Theatre Nursing Science (OTNS) as qualification and $42(32,6 \%)$ are Professional Nurses withoul the necessary qualification. Sec Figure 1 for the percentage comparison of categories of professional nurses.

\section{Biographical Duta}

$\underline{\operatorname{Sex}}$

$\mathrm{All}$ in the sample are femalc.

Residential Area

Most $(91,5 \%)$ of the personnel reside in Soweto Gcographic area where born and reared

Of these nurses, $67,5 \%$ were born and had spent their whole lifes in an urban arca, whilst $11,6 \%$ of them were reared in urban surroundings although born in a rural area. Sce Table 1 for the total distribution.

\section{$\Delta \mathrm{gc}$}

The frequency distribution of the age groups for all professional nurses were obtained and the percentage distribulion calculated, as shown in Figure 2 . Their mean age was 40,6 ycars. For a breakdown of the age distribution among nursing categories refer to Figure 3.

\section{Ethnic Grouns}

Baragwanath is a Black hospital but there are other race groups employed. Amongst the samplc population $128(99,2 \%)$ were Black and $1(0,8 \%)$ Coloured. The main ethnic groups arc Zulu $(26,3 \%)$ and Tswana $(25,6 \%)$.

\section{Marital Status}

Forty-lwo $(33,2 \%)$ respondents were single of whom $6(4,6 \%)$ werc traditionally marricd. Fifty-cight $(45 \%)$ respondents were married legally, $17(13,2 \%)$ were divorced of whom 1 $(0,8 \%)$ has relurned to Iraditional marriagc.

TABLE 1

Dlstribution of Geographic Areas in which Professlonal Nurses were born and reared, 1989

\begin{tabular}{|c|c|c|c|c|c|c|c|}
\hline \multicolumn{2}{|c|}{ Geographic Area } & \multirow{2}{*}{$\begin{array}{c}F \\
C P N\end{array}$} & \multirow{2}{*}{$\begin{array}{c}\text { F } \\
\text { SPN }\end{array}$} & \multirow{2}{*}{$\begin{array}{c}\mathbf{F} \\
\text { PN-OTNS }\end{array}$} & \multirow{2}{*}{$\begin{array}{c}\mathbf{F} \\
\mathbf{P N}\end{array}$} & \multirow{2}{*}{$\begin{array}{c}\mathbf{F} \\
\text { TOTAL }\end{array}$} & \multirow{2}{*}{$x$} \\
\hline Born & Reared & & & & & & \\
\hline Rural & Rural & - & 4 & 11 & 5 & 20 & 15,5 \\
\hline Rural & Urban & 2 & 5 & 8 & - & 15 & 11,6 \\
\hline Urban & Rural & - & - & 3 & 4 & 7 & 5,4 \\
\hline Uban & Urban & 1 & 18 & 35 & 33 & 87 & 67,5 \\
\hline \multicolumn{2}{|c|}{$N$} & 3 & 27 & 57 & 42 & 129 & 100 \\
\hline
\end{tabular}

TABLE 2

MARITAL STATUS OF PROFESSIONAL NURSES IN THE OPERATING THEATRE COMPLEX, 1989

\begin{tabular}{|c|c|c|c|c|c|c|}
\hline $\begin{array}{l}\text { MARITAL } \\
\text { STATUS }\end{array}$ & $\begin{array}{c}F \\
\text { CPN }\end{array}$ & $\begin{array}{c}F \\
\text { SPN }\end{array}$ & $\begin{array}{c}\mathbf{F} \\
\text { PN-OTNS }\end{array}$ & $\begin{array}{c}\mathbf{F} \\
\mathbf{P N}\end{array}$ & $\begin{array}{c}F \\
\text { TOTAL }\end{array}$ & $\mathbf{x}$ \\
\hline Single & & 2 & 16 & 19 & 37 & 28,6 \\
\hline Married - Legal & 2 & 18 & 26 & 12 & 58 & 45,0 \\
\hline Married - Traditional & & & 6 & & 6 & 4,6 \\
\hline Divorced and Married traditionally & 1 & & & & 1 & 0,8 \\
\hline Divorced & & 6 & 5 & 5 & 16 & 12,4 \\
\hline Widowed & & 1 & 3 & 5 & 9 & 7,0 \\
\hline Separaled & & & 1 & 1 & 2 & 1,6 \\
\hline
\end{tabular}


Nine (7\%) were widowed and $2(1,6 \%)$ were separated from their husbands. Sce Table 2

\section{Age of Motherhood}

Most respondents $(73,1 \%)$ had their first babies between the ages of 20 to 29 . Only $9(7,8 \%)$ women had delivered their first babies before the age of 20 . The mean age of motherhood was 26,1 years. As shown in Figure 4.

\section{Number of Children}

Most respondents $(75,2 \%)$, had 2 or fewer children of whom $14(10,9 \%)$ have had no children. The remaining $32(24,9 \%)$ respondents had 3 to 5 children. The mean number of children per respondent was 1,9 .

\section{Home Ownership}

Most respondents $(74,4 \%)$ are home owners of whom $45(46,8 \%)$ had provincial subsidised home loans, $11(11,5 \%)$ had loans from other sources, 11 financed their homesindependently, 8 had homes on which no money was owed and 11 nurses had homes on 99-year leasehold.

\section{Basic Schooling}

The highest educational standard achieved by the $12 \%$ respondents is shown in Figure 5. Most of the nurses $(79,8 \%)$ had attended a government shool for their secondary education and $16,3 \%$ had been to mission schools. With regard to the stage of life when respondents acquired their standard ten or matriculation certificates, only $42(43,3 \%)$ had commenced nursing in possession of such a certificate. Table 3 details times of obtaining this educational standard.

\section{Nursing Education}

Basic professional and advanced qualifications

By far the greatest number of respondents $(96,9 \%)$ have only General Nursing and Midwifery as basic professional qualifications with $4(3,1 \%)$ having obtained Community Health Nursing as well.

Additional qualifications excluding Operating Theatre Nursing Science (O.T.N.S.)

Additional post-basic qualifications, other than OTNS are held by $5(3,9 \%)$ nurses of whom 1 $(0,8 \%)$ holds three additional qualifications as shown in Table 4.

\section{Nursing Experience}

The respondents' years of experience since gaining General Nurse registration is shown in Figure 6 . The mean number of years experience was 14,9 . With specific reference to the post-basic diploma in Operating Theatre Nursing $79(61,3 \%)$ nurses have this diploma 7 $(5,4 \%)$ are doing the course and $43(33,3 \%)$ do not have this diploma. Among this latter group, 33 intend to acquire this qualifaction, 9 have no intention of doing so and one nurse gave no answer. Only $19(57,6 \%)$ of the respondents who wish to acquire this qualification have a standard ten or matriculation certificate. Of the remainder, 8 have a standard ninc and $6(18,2 \%)$ a standard eight cortificate.

\section{Participation in Continuing Formal Education}

Less than one-quarter (24\%) of the nurses arc furthering their studies after being assigned to the operating theatre complex. Of the $24 \%$ professional nurses who arc engaged in formal study, $12(38,7 \%)$ will graduate in Nursing
TABLE 3

TIME OF ACQUIRING STANDARD 10 OR MATRICULATION CERTIFICATES AMONG PROFESSIONAL NURSES IN THE OPERATING THEATRE COMPLEX, 1989

\begin{tabular}{|c|c|c|c|c|c|c|}
\hline TIME & $\begin{array}{c}F \\
\text { CPN }\end{array}$ & $\begin{array}{c}F \\
\text { SPN }\end{array}$ & $\begin{array}{c}\text { F } \\
\text { PN-OTNS }\end{array}$ & $\begin{array}{c}\mathbf{F} \\
\mathbf{P N}\end{array}$ & $\begin{array}{c}\text { F } \\
\text { TOTAL }\end{array}$ & $\%$ \\
\hline Before commencing any nursing & 1 & 2 & 25 & 14 & 42 & 43,3 \\
\hline After being enrolled as nurse & & & 1 & 1 & 2 & 2,1 \\
\hline After being registered as nurse & & & 2 & 3 & 5 & 5,2 \\
\hline After midwifery & & 3 & 16 & 5 & 24 & 24,7 \\
\hline \multirow[t]{2}{*}{ After theatre course } & 2 & 14 & 8 & & 24 & 24,7 \\
\hline & 3 & 19 & 52 & 23 & 97 & 100 \\
\hline
\end{tabular}

FREQUENCY

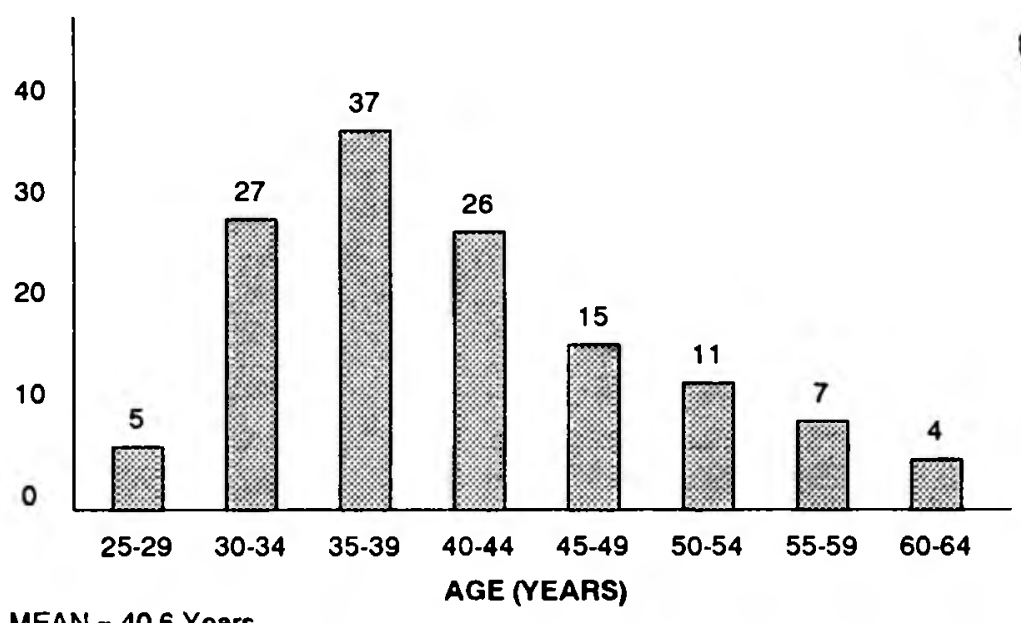

MEAN $=40,6$ Years

FIGURE 2

AGE DISTRIBUTION OF ALL CATEGORIES OF PROFESSIONAL NURSES IN THE OPERATING THEATRE COMPLEX, 1989.

\section{FREOUENCY}

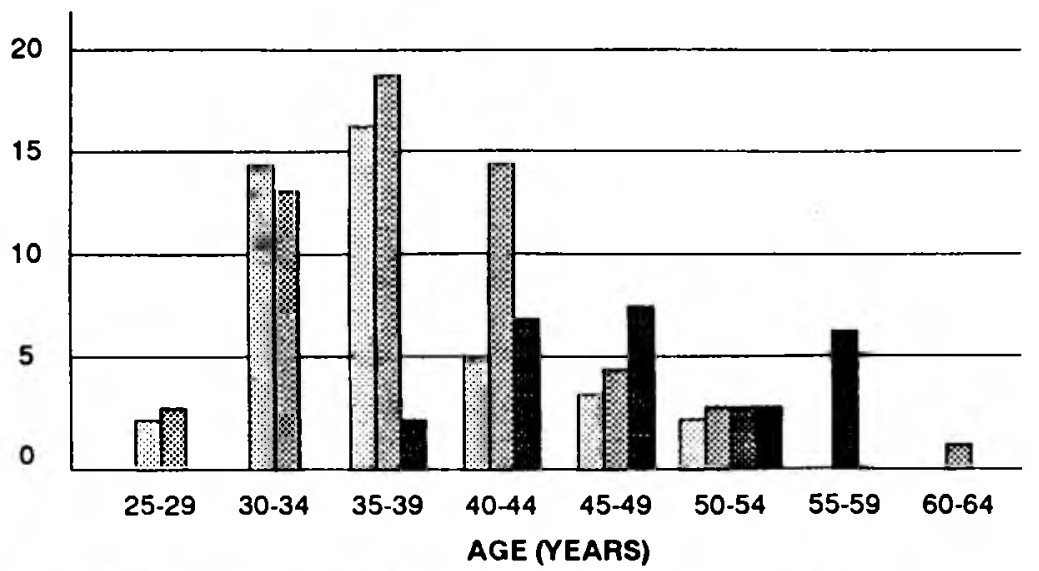

7 Prof Nurse Senior Prof Chief Prof Nurse OTNS Nurse

FIGURE 3

AGE DISTRIBUTION OF SPECIFIC GRADES OF PROFESSIONAL NURSES IN THE OPERATING THEATRE COMPLEX, 1989. 
TABLE 4

ADDITIONAL POST-BASIC NURSING QUALIFICATIONS, (EXCLUDING OPERATING THEATRE NURSING SCIENCE) HELD BY PROFESSIONAL NURSES IN THE OPERATING THEATRE COMPLEX, 1989

\begin{tabular}{|l|r|r|r|r|r|}
\hline \multicolumn{1}{|c|}{$\begin{array}{c}\text { POST-BASIC } \\
\text { QUUAIFICATIONS }\end{array}$} & CPN & SPN & PN-OTNS & PN & TOTAL \\
\hline Intensive Care & & & 1 & & 1 \\
\hline Nursing Education & & & 1 & & 1 \\
\hline N.Ed. + N. Adm. & 1 & & & & 1 \\
\hline .Ed. + N. Adm. + Ophth. & & 1 & & & 1 \\
\hline Ward Adm. + Clin. Instr. & 1 & & & & 1 \\
\hline
\end{tabular}

\section{FREQUENCY}

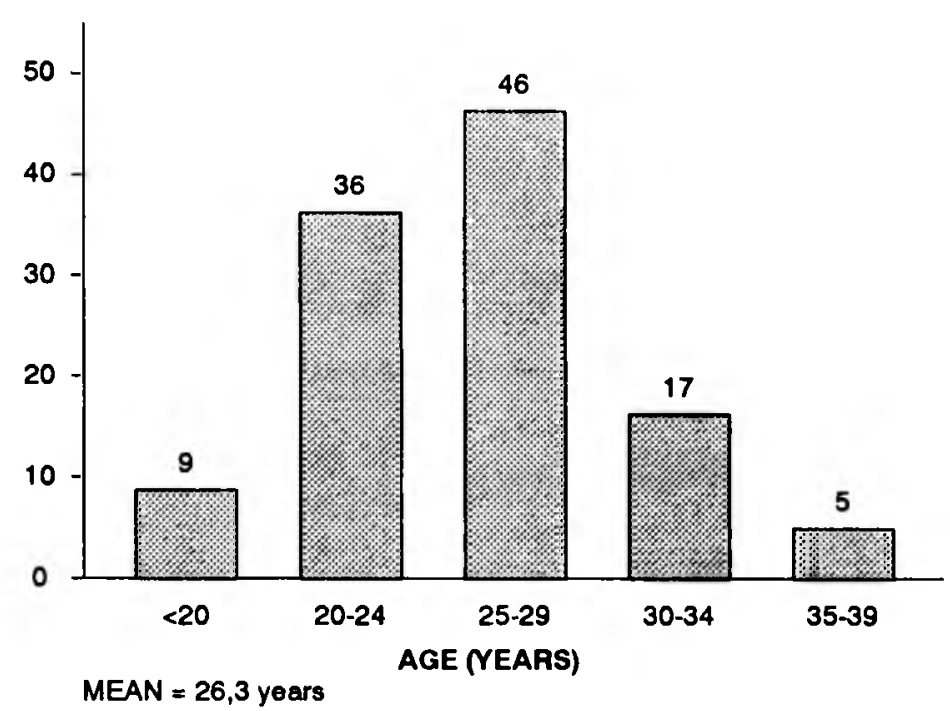

FIGURE 4

AGES OF MOTHERHOOD AMONG PROFESSIONAL NURSES IN THE OPERATING THEATRE COMPLEX, 1989.

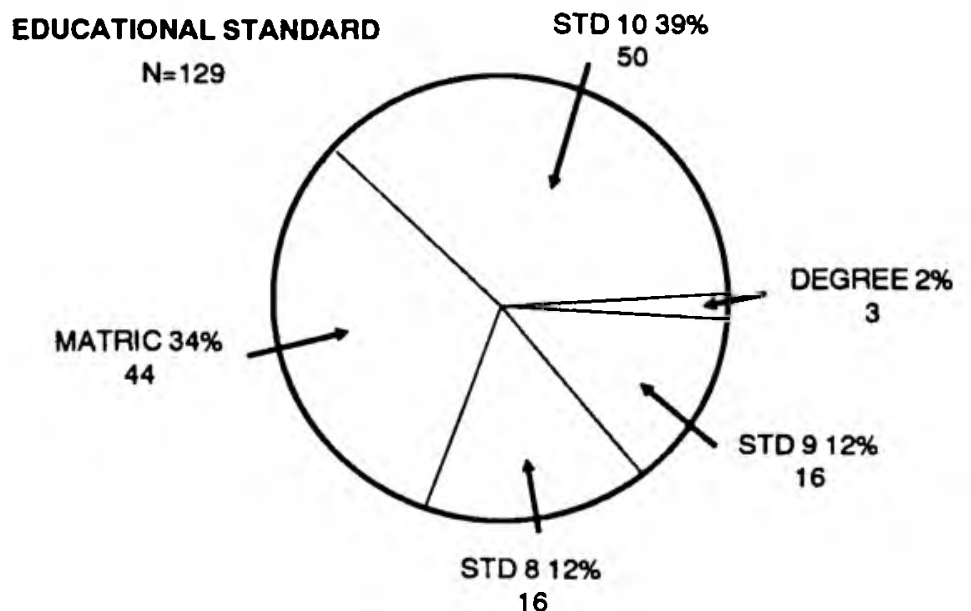

FIGURE 5

HIGHEST EDUCATIONAL STANDARD OF PROFESSIONAL NURSES IN THE OPERATING THEATRE COMPLEX, 1989.
Administration, $14(45,2 \%)$ in Nursing Education, $3(9,7 \%)$ in both disciplines and 2 in non-specified areas of study. Nearly three-quarters $(74,7 \%)$ of the non-participants in further studies envisage being engaged in future study.

Reasons for participation in Formal Education

The main reason given is that of personal and professional development $(\mathbf{7 6 , 7 \%})$. Personal achievement $(3,8 \%)$, promotion $(1,8 \%)$ and social status $(0,9 \%)$ were also considered and some respondents $(5,6 \%)$ gave two or more reasons for their participation, whilst $11,2 \%$ gave no response.

Reasons for intended non-participation in Formal Education

Financial reasons $(20,8 \%)$ and being too old $(20,8 \%)$ were the main reasons indicated although the same percentage of respondents gave no answer. Family problems $(12,5 \%)$, preference for another discipline $(8,3 \%)$, no desire to study $(4,2 \%)$ and an unspecified other reason $(4,2 \%)$ also were indicated.

\section{Non-nursing Qualifications}

Non-nursing qualifications were indicated by $11,7 \%$ of respondents with $16,4 \%$ omitting an answer. Seven $(5,4 \%)$ of the professional nurses hold a teaching diploma, one has a technical and another a secretarial diploma. Other qualifications given were interior decorating and nower arranging $(3,1 \%)$, bookkeeping and accounting $(0,8 \%)$ and nursery supcrvision $(0,8 \%)$. Most respondents $(72,9 \%)$ held no non-nursing qualifications.

Experience in Operating Theatre Nursing Experience before obtaining Diploma OTNS

Most respondents $(64,4 \%)$ had five years or less experience with $35(27,1 \%)$ between 6 to 10 years, $8(6,2 \%)$ between 11 to 15 years and 3 $(2,3 \%)$ betwcen 16 to 20 years.

\section{Expcrience after obtaining Diploma OTNS}

Of the 87 professional nurses who hold the required qualification, $33(37,9 \%)$ have five years or less experience. Twenty five $(28,8 \%)$ respondents have between 16 to 20 years experience and $9(10,3 \%)$ beyond 20 years.

The total experience of all categories of professional nurses in operating theatre nursing is shown in Figure 7.

\section{Experience in Present Position}

The $54(41,9 \%)$ respondents who have held their present positions for five years or less include two Chief Professional and nine Senior Professional Nurses. Among the professional nurses making up the remaining numbers, 13 possessed the qualification OTNS and $\mathbf{3 0}$ did not.

One Chief Professional Nurse has been in her present position between 11 and 15 years. Among the Senior Professional Nurses seven had been in their present position between 6 to 10 years, eight between 11 to 15 years, two between 16 to 20 years and one for morc than 20 ycars. The Professional Nurses who hold the OTNS, which total qualification is $27(47,4 \%)$, have been in their present positions for between 6 to 10 years. Another twelve have held their positions for 11 to 15 years. Of the remaining five, two have been in their present position for 


\section{PERCENTAGE}

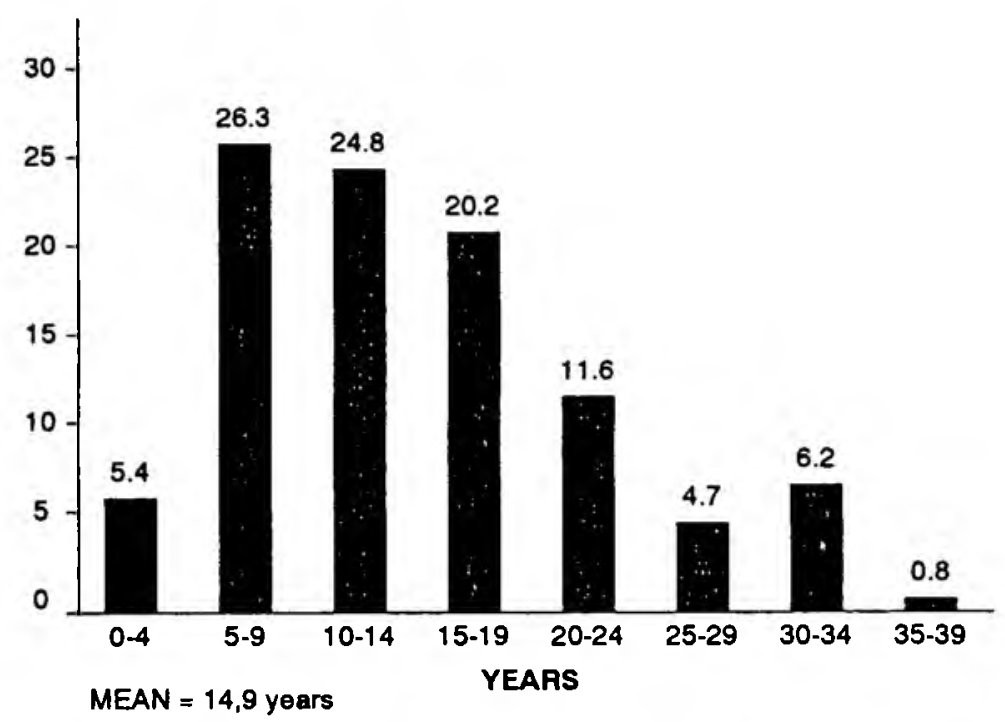

FIGURE 6

NURSING EXPERIENCE OF PROFESSIONAL NURSES IN THE OPERATING THEATRE COMPLEX AFTER GRADUATION IN GENERAL NURSING.

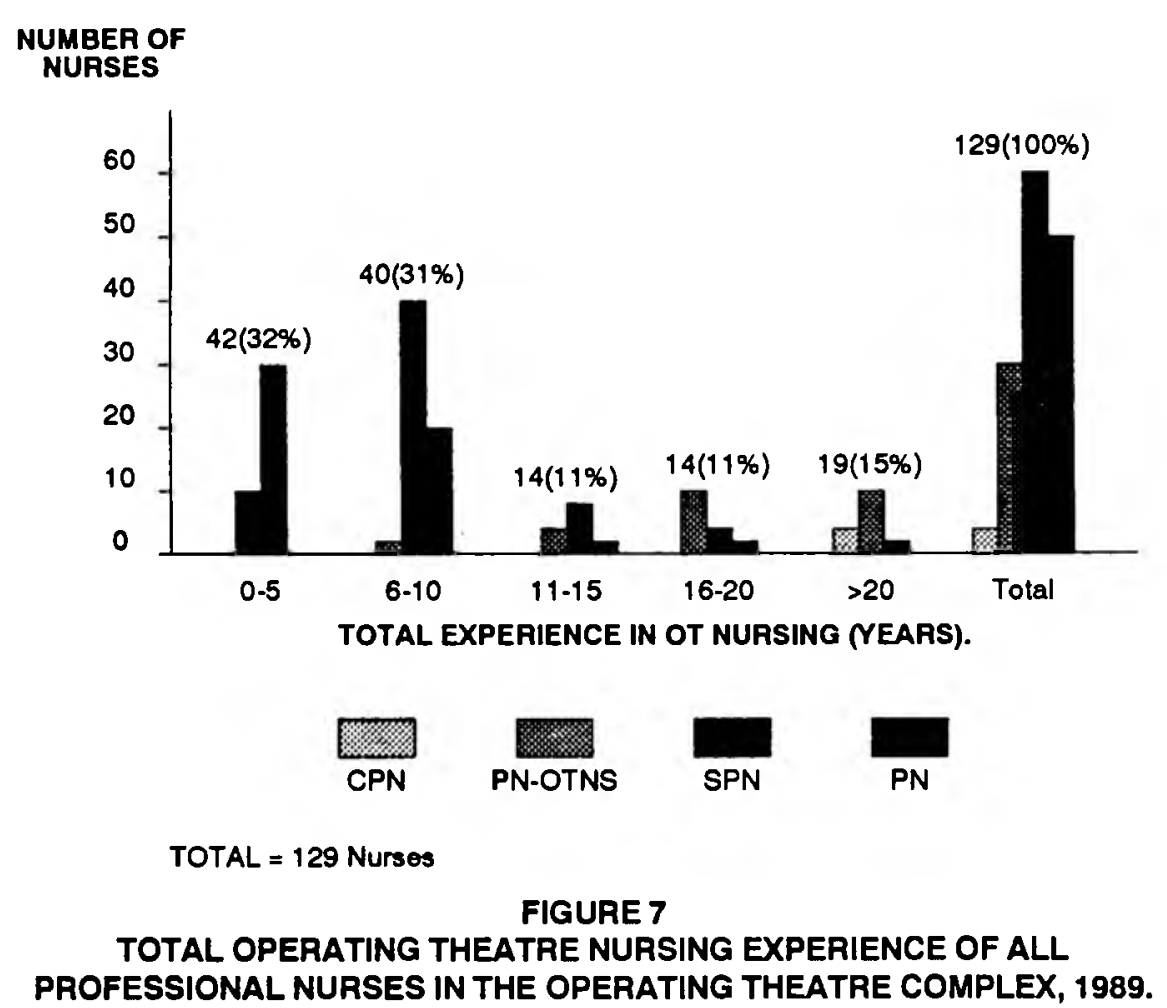

16 to 20 years and three for more than 20 years. The 12 Professional Nurses without the OTNS qualification, showed that ten had been in their present position for 6 to 10 years with one in the 11 to 15 years bracket and the last one holding her position for 16 to 20 years.

First Choice of Specialization within Operating Theatre Nursing

The most common areas of preference identified were general surgery $(10,9 \%)$, orthopaedic surgery $(10,1 \%)$, post-anaesthesia nursing $(10,1 \%)$ and clinical teaching $(9,3 \%)$. Eighteen respondents $(14 \%)$ had more than one first choice. No-one selected facio-maxillary as their chosen area of specialization and only $0,8 \%$ study) each received one vote. One respondent did not indicate her choice.

\section{Choice of nursing practice}

The majority of respondents $(55,8 \%)$ indicated that they would like to remain in operating theatre nursing. Details of preferred broad areas of work are reflected in Table 5.

\section{CONCLUSIONS AND \\ RECOMMENDATIONS}

\section{Categories}

Four categories of professional nurses have been identified in the J.D. Allen operating theatre complex of Baragwanath hospital:-

1. The Professional Nurse with the Diploma in Operating Theatre Nursing Science or engaged in studying for the diploma, practising at a junior nursing level, constitutes $44,2 \%$ of the staff establishment. This category provides a more than adequate human resource supply for future promotion.

2. The Professional Nurse category without the necessary post-basic qualification constituted $32,6 \%$ of staff whom selected candidates could be drawn for future post-basic training

3. At middle-management level, the Chief Professional Nurse category constitutes 2,3\% of the total staff complement. This latter percentage may be too low when one considers that within the hospital, twowards are allocated to a nurse of this particular category.

4. The Senior Professional Nurse category constituted $20,9 \%$ of total staff which may be considered as rather low in view of future promotion opportunities.

It is recommended that the projected new staff establishment should have increased numbers in both Chief and Senior Professional Nurse grades.

With regard to Chief Professional Nurse category, one post should be assigned to every three to four operating theatres depending on the degree of specialized nursing practice delivered. The same consideration should be given to nursing oriented areas such as anaesthetic nursing, post anaesthesia (recovery room) nursing and the sterile supply production unit as first priorities.

The recommended increase in posts for the Senior Professional Nurse category would increase promotion opportunities for a number of middle-aged and very experienced professional nurses who would otherwise have little chance of being recognized.

\section{Biographical Picture}

The greater majority of the professional nurses reside in Soweto $(91,5 \%)$ showing that Baragwanath hospital draws most of its nursing staff from the surrounding township. Just over $80 \%$ of the professional nurses fell in the combined age group of $\mathbf{3 0}-49$ years (mean age of 40,6 years) indicating that they are in the middle years of their professional lives. In the 
TABLE 5

PREFERRED CHOICE OF SPHERE OF NURSING PRACTICE AMONG PROFESSIONAL NURSES IN THE OPERATING THEATRE COMPLEX, 1989

\begin{tabular}{|l|r|r|r|r|r|r|}
\hline \multicolumn{1}{|c|}{$\begin{array}{c}\text { CHOICE OF NURSING PRACTICE } \\
\text { ONCE DEGREED }\end{array}$} & \multicolumn{1}{c|}{$\begin{array}{c}\text { F } \\
\text { CPN }\end{array}$} & \multicolumn{1}{c|}{$\begin{array}{c}\text { F } \\
\text { SPN }\end{array}$} & \multicolumn{1}{c|}{$\begin{array}{c}\text { FN-OTNS } \\
\text { PN }\end{array}$} & \multicolumn{1}{c|}{ TOTAL } & $\%$ \\
\hline Remain in area of Theatre Specialization & 1 & 7 & 14 & 20 & 42 & 32,6 \\
\hline Clinical Teaching in Operating Theatre & & & 9 & 3 & 12 & 9,3 \\
\hline $\begin{array}{l}\text { Administrative/Supervision in Operating } \\
\text { Theatre }\end{array}$ & 1 & 8 & 6 & 3 & 18 & 13,9 \\
\hline Administrative post in Hospital & & & & 1 & 1 & 0,8 \\
\hline Formal Teaching - College/University & & 2 & 2 & 1 & 5 & 3,9 \\
\hline Nursing Research & & & 2 & 2 & 4 & 3,1 \\
\hline Community Nursing & & 2 & 13 & 8 & 23 & 17,8 \\
\hline None of Above & 1 & 1 & 3 & & 5 & 3,9 \\
\hline No Answer & & 7 & 8 & 4 & 19 & 14,7 \\
\hline O & 3 & 27 & 57 & 42 & 129 & 100 \\
\hline
\end{tabular}

age group of 55 years and above, eight professional nurses were identified of whom seven are Senior Professional Nurses. This information implies that firstly, close counselling should be offered to those near retirement in order for them to reap the best benefits when the time comes. Secondly, specific consideration will have to be given to developing management skills in potential candidates for future promotion. All three Chief Professional Nurses are in the age group $50-54$ years. Although one Senior Professional Nurse with the necessary experience in Administration/ supervision and engaged in full-time formal study could be a potential candidate for promotion, more attention should be given to the development of others for the remaining proposed posts.

The main ethnic groups to which the professional nurses belong were identificd as Zulu $(26,3 \%)$ and Tswana $(25,6 \%)$. The Xhosa g. $(12,4 \%)$ headed the 11 minority groups. In contrast to the Tswanas who have roots in the Transvaal the Zulu group migrated from Natal to become established in this area. An interesting fact drawn from the study is that only $37,9 \%$ of the professional nurses are married to men of the same ethnic group and most of these professional women $(66,7 \%)$ prefer and practise their own culture in preference to that of their husbands which may indicate the reversal of sexual dominant roles. Results indicated that nearly $\mathbf{5 0 \%}$ of the professional nurses may be the breadwinners of their families and that nearly $75 \%$ of them are home owners, cither as a family unit or as sole owners.

The mean age of motherhood was 26,1 ycars indicating a relatively late commitment to sexual relationships. In addition, most of the professional nurses had two or less children $(75,2 \%)$ so that the average number of children per woman at 1,9 is below zero-growth rate as calculated by Smith (1989:15) and Rhoodie \& Swart (1971).

If one considers that $29,4 \%$ of the respondents intend to enlarge their respective families, then the figure may change somewhat in the near future as the mean age of the respondents at 40,6 years is within the child-bearing group of 15 to 49 years (Rhoodic and Swart, 1971:88). Nevertheless, this is a significant trend among urbanized and professional Black women who show clearly the results of planned family life.

The majority of professional nurses $(72,9 \%)$ have a matriculation or standard ten ccrtificate with an additional $2,3 \%$ having obtained a degree, reflecting the educational trend associated with Black urbanization.

This trend is substantiated when one considers that $43,3 \%$ of the professional nurses obtained their highest school education before they commenced nursing and is significant among the younger age group. In addition, nearly $50 \%$ obtained their highest educational standard after completing midwifery or the OTNS diploma. Secondary education was obtained mostly at government schools which could have contributed to some not completing their secondary education in view of urban unrest over the last 15 years. Since $24,8 \%$ of the professional nurses lack matriculation or standard ten certificates further requests for accommodation of their learning needs can be expected.

The 3 professional nurses who have University degrees all obtained these after completing the theatre course.

\section{Nursing Education}

\section{Basic and Advanced Qualifications}

By far the greatest number $(96,6 \%)$ of professional nurses have only General Nursing and Midwifery as basic professional qualifications with an additional $3,1 \%$ having obtained Community Health Nursing as an advanced qualification, this may be regarded as inappropriate for the operating theatre situation.

\section{Additional Qualifications - Excluding O'TNS}

With the exclusion of the Diploma in Operating Theatre Nursing Science, 3,9\% women held additional qualifications. Intensive Care Nursing as one, is very appropriate for post-anaesthesia care in view of the four intensive care beds in this area. Ophthalmic Nursing as another, is also appropriate for the situation although all ophthalmic surgery is performed at St. John's hospital in affiliation with the main hospital

One person holds the Diploma in Ward Administration and Clinical Instruction as well as Oncology (overseas) which are both outdated for the present situation in a middle-management position.

Other useful and suitable qualifications identified were Nursing Education and Nursing Administration of which both are held by two persons, one being in a Chicf Professional Nurse's position. The person holding Nursing Education works in clinical teaching within the department.

It is recommended that the Chief Professional Nurse with the outdated qualifications be advised to consider formal study applicable to the position she holds. In addition, the Senior Professional Nurse with the dual qualifications in education and administration has many years of experience in this discipline and should be incorporated within the proposed revised organizational staff structure.

\section{Nursing Experience}

The number of years of experience of the professional nurses range from less than 5 years to almost 39 years since General Nurse registration. The length of time spent in the nursing profession by the Black professional nurses indicates a very stable work force.

\section{Diploma in Operating Theatre Nursing Science}

About two-thirds of the professional nurses possess the necessary posi-basic qualification $(61,3 \%)$ or are engaged as students on the course $(5,4 \%)$ which provides for a considerable input in sctting the training standards. This input could be increased. Of the $33,3 \%$ of professional nurses who do not possess the necessary diploma in this nursing discipline, more than $75 \%$ intend to acquire it. Although $42,2 \%$ lack matriculation or standard ten, the South African Nursing Council should be urged on special grounds to have a few admitted to the course. Since many have experience in operating theatre nursing, it may not be required to do the course. Training standards have to be set, however, and for clinical specialization the nccessary post-basic qualification is obligatory

\section{Formal Tertiary Education}

Only $24 \%$ of professional nurses are engaged in formal study through the University of South Africa on a part-time basis and one is a full-time student at Witwaterstand University. Of these $38,7 \%$ will graduate in Nursing Administration, 45,2\% in Nursing Education and $3,2 \%$ in both areas. Nearly $75 \%$ of the non-participants in formal study indicate the intention to do so at a later stage. Since one can have only a limited number of top rank posts these nurses may be over-qualified for their positions. This may not present a major problem in the near future since the infiltration of graduates will be gradual but once the majority who intend future study qualify, the situation may change radically. The highly intellectual nurse may not want to partake in direct patient care unless delibcrate efforts are made to introduce 
planned change of attitudes. The clinical nurse specialist concept may provide some outlet for possible conflict situations but is not the ultimate solution since basic patient care providers will always be required.

\section{Reasons for participation in Formal Education}

Whether the professional nurses are engaged in or intending formal study, the main reason for these endeavours is given as being for personal and professional development. The validity of this reason is doubted as the nursing profession carries a high degree of social status among the Black community. Since the first graduates emerged in the community the wearing of graduate gowns in highly valued funeral processions has lent the necessary recognition to the acquired social status of the academic.

Reasons for intended non-participation in Formal Education

Those professional nurses (20\%) who have no intentions of future formal study ascribe their main reasons to financial and age factors $(20,8 \%$ each). To a lesser degree, family problems $(12,5 \%)$ and preference for a discipline other than nursing $(8,3 \%)$ are indicated.

\section{Non-nursing Qualifications}

Nearly $12 \%$ of the professional nurses possess additional qualifications. A teaching diploma is held by $5,4 \%$. This may not be of a high level since most persons only possessed a standard eight certificate before obtaining a teaching qualification.

\section{Experience in Operating Theatre Nursing}

The most outstanding finding of the study is the fact that such a high percentage of professional nurses had been practising operating theatre nursing for such a lengthy period of time. If one looks at the total experience of these women one finds the mean years of experience to be 10,4 years but $14,6 \%$ exceed 20 years. Considering the high-technology situation prevailing in the J.D. Allen operating theatre complex, the demonstrated pool of experience in this discipline indicates that many of these nurses are experts in their field.

\section{Experience in Present Position Held}

The $41,9 \%$ of professional nurses who have held their present positions for five years or less include two Chief Professional Nurses and nine Senior Professional Nurses which signifies active professional mobility in the hierarchical structure of the hospital. What is of concern, is the large percentage $(77,2 \%)$ of Professional Nurses who qualify for promotion in terms of the necessary post-basic qualification and length of experience in this particular discipline (more than 6 years and exceeding 20 years) The recommendation for increased senior posts can only be reiterated.

All but one professional nurse held permanent appointments. This particular person who was identified may be in a locum post, but it is recommended that the matter be investigated.

First Choice of specialization within Operating Theatre Nursing

The areas of first choice indicated seem to be general surgery, orthopaedic surgery, post-anaesthesia care and clinical teaching. The least preferred areas are facio-maxillary and
E.N.T. surgery which may present problems once these specialities are allocated to their own individual operating theatres as is anticipated for the near future. It is recommended that problems related to each of these specialities be identified and suitable solutions found.

Operating Theatre Nursing as discipline of choice

Nearly $9 \%$ of professional nurses indicated that they prefer nursing disciplines other than operating theatre nursing and it is recommended that these nurses be interviewed and arrangements made to move them out of the department.

\section{Choice of Nursing Practice when Graduated}

The indication that $55,8 \%$ of professional nurses would like to remain in operating theatre nursing once graduated provides additional support that this particular nursing discipline is indeed their discipline of choice. Development programmes have better results if the participants have the right interest at heart. In addition, quality patient care becomes a personal and valued commitment which generates recognition of such commitment. A very positive move towards clinical nurse specialist practice may be assumed in view of the fact that $32,6 \%$ of the professional nurses would prefer to remain in their particular areas of specialization once graduated. It is recommended that specific attention be given to orientate staff towards this concept and at the same time coach attitudes in the right direction. A close watch will be kept on those professional nurses who would graduate in time but prefer other nursing disciplines than operating theatre nursing. The aim would be to lend assistance towards individual goal realization.

\section{LIMITATIONS OF TIE STUDY}

Although particular care was taken in designing the questionnaire using a collective approach which included the suggestions of all three Chief Professional Nurses, two small problems were encountered during the analysis of the data.

The first problem pertained to the residing township. The general opinion was that Soweto is seen as a city and each area within it is seen as a township. On the contrary, about $42 \%$ of respondents indicated that Soweto is the township in which they reside thereby excluding their precise place of residence. Since exact location would fascilitate transport arrangements in times of crisis, it was thought necessary to request the required information by means of a written list of the respondent's names.

The second problem concerned some respondents' perception of the meaning of formal education. About $2 \%$ of respondents considered post-basic nursing courses to be part of formal education and even indicated that they would be eligible to register additional qualifications in Nursing Education and Administration. These respondents were busy with the course for the Diploma in Operating Theatre Nursing Science. It was thus necessary to alter their answers in view of this misperception

Although the sample constitutes $92 \%$ of the operating theatre nursing staff which may be regarded as a realistic representation of the total staff establishment, it is nevertheless incomplete. Of specific concem is the fact that some of the outstanding questionnaires included those of nurses who hold the Diploma in Operating Theatre Technique $(2,8 \%)$ and it wil be necessary to extend this study at a later stage to obtain a complete profile of staff.

\section{ACKNOWLEDGEMENTS}

1. To the Chief Superintendent and Chief Nursing Service Manager of Baragwanath hospital for granting permission to carry out the study.

2. To Mrs J T Nortje for typing the script.

3. To the Professional Nurses of the J.D. Allen operating theatres complex for their cooperation as usual and their trust.

4. To Dr P Sarelli and his team in Cardiology for producing the computorized graphics.

\section{BIBLIOGRAPHY}

Alexander, E.L. 1972: Nursing Administration in the hospital health care system. St Louis: C.V. Mosby.

Allen, L.A. 1958: Management and Organization. Tokyo: McGraw-Hill Kogakusha

Arndt, C. and Huckabay, L.M.D. 1980: Nursing Administration. St. Louis: C.V. Mosby.

Beach, D.S. 1980: Personnel the management of people at work. New York: McMillan. Fourth Edition.

Beatty, R.W. and Schneier, C.E. 982: Personnel Administration Reading, Massachusetts: Addison-Wesley.

Becker, P. 1974: Tribe to Township St Albans: Panther Books.

Brink, H.L.S. 1988: A Profile of the Registered Nurse Tutor in the R.S.A. Curationis Vol. 11(1).

DeBella, S. Martin, L. and Siddall, S. 1986: Nurses' Role in Health Care Planning. Norwalk, Connecticut: Appleton-CenturyCrofts.

DiVincenti, M. 1977: Administering Nursing Service. Boston: Little Brown. Second Edition.

Gillies, D.A. 1982: Nursing Management: a systems approach. Philadelphia: W.B. Saunders.

Groah, L.K. 1983: Operating Room Nursing: the perioperative role. Reston: Reston Publishing Company.

Hamilton, S. 1988: Quality Assurance in Perioperative Nursing Practice. Johannesburg: Randse Afrikaanse Universiteit. 
Hamric, A.B. and Spross, J. 1983: The Clinical Nurse Specialist in Theory and Practice. Orlando: Grune \& Stratton.

Hein, E.C. and Nicholson, M.J. 1986: Contemporary Leadership Behaviour: Selected Readings. Boston: Little Brown. Second Edition.

Myburgh, A.C. 1981: Anthropology for Southem Africa. Pretoria: J.L. van Schaik.

Paton, F. 1988: UNISA Qualified Nurse Educators. A Profile according to three post categories. Curationis Vol. 11(4) December.

Raubenheimer, S. 1987: Demografiesc Verandering. Siellenbosch Universiteitsuitgewers.

Rhoodie, N.J. en Swart, C.F. 1971: Sosiale Demografie. Pretoria: Academica

Smith, J.B. 1989: Die vraag na onderwys. Monografie. Johannesburg: Randse Afrikaanse Universiteit.
Terry, R.W. 1963: Man in Africa. Johannesburg: The Institute for the Study of Man in Africa.

E. F. SMITH
B. Cur Ed et Ad, D.N.Ed, D.N.Ad, C.H.N.,
O.N.S., R.M., RN.
J.D. Allen Operating Theate Complex,
General Intensive Care Unit, Resuscitation
Unit and Cardiology.
Baragwanath Hospital.
HH.M. UYS
D.Cur.
Department of Nursing
RandAfrikaans University.

